\author{
Al-wardah: Jurnal Kajian Perempuan, Gender dan Agama \\ Volume : 13 No 1. Edisi Juni 2019 \\ ISSN: 1907-2740, E-ISSN: 2613-9367 \\ DOI :10.46339/al-wardah.v13i1.155
}

\title{
DINAMIKA PERNIKAHAN DINI
}

\author{
Adiyana Adam \\ IAIN Ternate,Indonesia \\ adiyanaadamm@gmail.com
}

\begin{abstract}
Abstrak
Pernikahan usia dini adalah peristiwa pernikahan yang dilakukan oleh anak dibawah 16 tahun bagi perempuan dan dibawah 19 bagi laki-laki. Faktor intern yang datang dari dalam yaitu keinginan dari individu itu sendiri sedangkan faktor ektern yaitu faktor ekonomi orang tua, faktor pendidikan, dan faktor orang tua atau keinginan dari orang tua. Banyak remaja terjebak dalam pernikahan usia muda, terutama mereka yang berasal dari keluarga kurang mampu, sehingga mereka memilih menikah di usia muda untuk mengurangi beban ekonomi keluarga. Banyak kemungkinan resiko pernikahan usia muda, baik resiko fisik maupun psikis. Hasil penelitian menunjukkan bahwa terdapat beragam faktor yang mempengaruhi pernikahan usia muda. Factor utama penyebabnya adalah faktor ekonomi dan faktor pendukung lainnya adalah pengaruh teman sebaya, keinginan dari informan, keluarga, dan hamil di luar nikah.
\end{abstract}

Kata Kunci: pernikahan Dini

\begin{abstract}
Abstact
Early marriage is a marriage event performed by children under 16 years of age for women and below 19 for men. Internal factors coming from within the desire of the individuals themselves while ektern factor is the economic factor of parents, educational factors, and factors of the parents or the desire of the parents Many teenagers trapped in marriage a young age, especially those from poor families, so they chose to marry at a young age to reduce the economic burden of the family. Many possible risk of early age marriage, be it physical or psychological risk. The results showed that there are various factors that influence the occurrence of marriage at a young age. The main factor is the cause of economic factors and other supporting factors such as the influence of peers, the desire of the informant, families, and pregnant out of wedlock.
\end{abstract}

Keywords: early-age marriage

\section{A. PENDAHULUAN}


Pernikahan adalah upacara pengikatan janji nikah yang dirayakan atau dilaksanakan oleh dua orang dengan maksud meresmikan ikatan perkawinan secara norma agama, norma hukum, dan norma sosial. Upacara pernikahan memiliki banyak ragam dan variasi menurut tradisi suku bangsa, agama, budaya, maupun kelas sosial. Pernikahan dini terjadi dengan alasan untuk menghindari fitnah atau berhubungan seks di luar nikah. Ada juga orang tua yang menikahkan anak mereka yang masih remaja karena alasan ekonomi. Dengan menikahkan anak perempuan, berarti beban orang tua dalam menghidupi anak tersebut berkurang, karena anak perempuan akan menjadi tanggung jawab suaminya setelah menikah.

Undang-Undang Republik Indonesia No. 1 tahun 1974 pasal 7 mengatur batas minimal usia untuk menikah di mana pernikahan hanya diizinkan jika pria sudah mencapai usia 19 tahun dan pihak wanita sudah mencapai usia 16 tahun.. Sementara itu, apabila berdasarkan ilmu kesehatan, umur ideal yang matang secara biologis dan psikologis adalah 20 sampai 25 tahun bagi wanita, kemudian umur 25 sampai 30 tahun bagi pria. Usia tersebut dianggap masa yang paling baik untuk berumah tangga, karena sudah matang dan bisa berpikir dewasa secara rata-rata. Menurut Departemen Kesehatan RI (2011),remaja dibagi menjadi masa remaja awal yaitu10-13 tahun, masa remaja tengah 14-16 tahun dan masa reamaja akhir yaitu 17-19 tahun. sementara menurut WHO remaja adalah periode dari pertumbuhan dan perkembangan yang terjadi setelah masa anak-anak dan sebelum dewasa, dari usia 10-19 tahun. Dan tujuan dari pernikahan yaitu untuk membentuk keluarga yang bahagia, sejahtera dan kekal berdasarkan ketuhanan Yang Maha Esa

Untuk merealisasikan tujuan mulia ini diantaranya adalah harus didukung kesiapan fisik atau materi dan kematangan jiwa (mental) dari masing-masing calon mempelai. Bagi seorang pemuda, usia untuk memasuki gerbang perkawinan dan kehidupan berumah tangga pada umumnya dititikberatkan kepada kematangan jasmani dan kedewasaan pikiranya serta kesanggupanya untuk memikul tanggung jawab sebagai suami dalam rumah tangganya. Itulah patokan yang sebaiknya para pemuda, kecuali jika ada fakta-fakta lain yang menyebabkan pernikahanya harus dipercepat guna 
memeliharanya dari dosa yang akan membawa akibat lebih burtk baginya. Bagi seorang gadis, usia melakukan perkawinan itu karena adanya kemungkinan dalam waktu singkat terjadi kehamilan dan persalinan pertama harus memperhitungkan kematangan jasmani dan rohaninya yang memungkinkan ia dapat menjalankan tugas sebagai istri dan ibu dengan sebaik-baiknya. Syariat Islam mengajarkan bahwa salah satu syarat utama keabsahan suatu syariat adalah apabila yang bersangkutan telah akil balig. Oleh karena itu, seorang pria yang belum balig belum dapat melaksanakan qabul secara sah dalam suatu akad nikah. Perlu diketahui bahwa dalam pelaksanaan akad nikah, calon mempelai pria harus mengatakan qabul (penerimaan nikah)

Perkawinan bagi manusia merupakan hal yang penting, karena dengan sebuah perkawinan seseorang akan memperoleh keseimbangan hidup baik secara sosial biologis, psikologis maupun secara social. Sementara itu secara mental atau rohani mereka yang telah menikah lebihbisa mengendalikan emosinya dan mengendalikan nafsu seksnya. Kematangan emosi merupakan aspek yang sangat penting untuk menjaga kelangsungan perkawinan. Keberhasilan rumah tangga sangat banyak di tentukan oleh kematangan emosi, baik suami maupun istri.

Pada hakikatnya pernikahan bukanlah hanya sebuah ikatan yang bertujuan untuk melegalkan hubungan biologis saja, namun juga untuk membentuk sebuah keluarga yang menuntut pelaku pernikahan untuk mandiri dalam berpikir dan menyelesaikan masalah dalam pernikahan.

Tujuan pernikahan dalam agama ialah selain untuk mendapatkan keturunan juga untuk memenuhi petunjuk agama dalam rangka mendirikan keluarga yang harmonis, sejahtera dan bahagia. Harmonis dalam menggunakan hak dan kewajiban anggota keluarga. Sejahtera artinya terciptanya ketenangan lahir dan bathin disebabkan terpenuhinya keperluan hidup lahir dan bathinnya, sehingga timbullah kebahagiaan yakni kasih sayang antar anggota keluarga

Seseorang yang telah melakukan ikatan lahir batin antara pria dengan wanita sebagai seorang suami istri dengan tujuan membentuk keluarga, baik yang dilakukan secara hukum maupun secara adat/kepercayaan dapat dikatakan pula sebagai 
pernikahan. Apabila suatu pernikahan tersebut dilakukan oleh seseorang yang memiliki umur yang relatif muda maka hal itu dapat dikatakan dengan pernikahan dini. Umur yang relatif muda yang dimaksud tersebut adalah usia pubertas yaitu usia antara 10-19 tahun. Sehingga seorang remaja yang berusia antara 10-19 tahun yang telah melakukan ikatan lahir batin sebagai seorang suami istri dengan tujuan membentuk keluarga dikatakan sebagai pernikahan dini atau pernikahan muda. Atau dapat di katakan bahwa pernikahan usia muda adalah sebuah pernikahan yang salah satu atau kedua pasangan berusia di bawah 18 tahun atau sedang mengikuti pendidikan di sekolah mengenah atas. Jadi, sebuah pernikahan disebut pernikahan dini, jika kedua atau salah satu pasangan masih berusia dibawah 18 tahun (masih berusia remaja)

\section{B. PEMBAHASAN}

Konsekuensi dari pernikahan usia muda dan melahirkan di usia remaja adalah berisiko untuk melahirkan prematur dan berat badan lahir rendah. Wanita yang menikah pada usia dini mempunyai waktu yang lebih panjang berisiko untuk hamil dan angka kelahiran juga lebih tinggi. Perkawinan usia remaja juga berdampak pada rendahnya kualitas keluarga, baik ditinjau dari segi ketidaksiapan secara psikis dalam menghadapi persoalan sosial maupun ekonomi rumah tangga, risiko tidak siap mental untuk membina perkawinan dan menjadi orang tua yang bertanggung jawab, kegagalan perkawinan, kehamilan usia dini berisiko terhadap kematian ibu karena ketidaksiapan calon ibu remaja dalam mengandung dan melahirkan bayinya..

Menurut Eka Khaparistiadan Edward Faktor yang menyebabkan pernikahan usia dini adalah kemauan sendiri karena sudah merasa saling mencintai, faktor dorongan orang tua atau keluarga, juga faktor pendidikan yang begitu rendah yang di sebabkan oleh kondisi ekonomi yang serba pas-pasan

Menurut Sarwono (2007), bahwa salah satu faktor terjadinya pernikahan dini lainnya adalah pendidikan remaja dan pendidikan orang tua. Dalam kehidupan seseorang, dalam menyikapi masalah dan membuat keputusan termasuk hal yang lebih kompleks ataupun kematangan psikososialnya sangat dipengaruhi oleh tingkat 
Dinamika Pernikahan Dini

pendidikan seseorang, tingkat pendidikan maupun pengetahuan anak yang rendah dapat menyebabkan adanya kecenderungan melakukan pernikahan di usia dini 

Hal ini sejalan dengan penelitian yang dilakukan oleh Nandang, dkk (2007) yang menunjukkan bahwa remaja muda yang berpendidikan rendah memiliki resiko (ods ratio) 4,259 kali untuk menikah dini daripada remaja muda yang berpendidikan tinggi. Remaja yang memiliki latar belakang pendidikan yang tinggi memiliki resiko lebih kecil untuk menikah dini dibandingkan dengan remaja yang memiliki latar pendidikan rendah. Tingkat pendidikan merupakan salah satu faktor yang mempengaruhi seseorang dalam menyikapi masalah dan membuat keputusan ataupun kematangan psikososialnya.

Pendidikan orang tua juga memiliki peranan dalam keputusan buat anaknya, karena di dalam lingkungan keluarga ini, pendidikan anak yang pertama dan utama. Juspin dkk (2009: 89-94) mengemukakan bahwa peran orang tua terhadap kelangsungan pernikahan dini pada dasarnya tidak terlepas dari tingkat pengetahuan orang tua yang dihubungkan pula dengan tingkat pendidikan orang tua. Hal ini sejalan dengan penelitian yang dilakukan oleh Nandang, dkk yang menunjukkan bahwa ada hubungan antara pendidikan orang tua pada wanita dewasa muda dengan resiko sebesar 7,667 kali lipat. Remaja yang memiliki latar belakang orang tua berpendidikan rendah maka memiliki resiko lebih besar untuk menikah dini daripada remaja yang memiliki latarbelakang orang tua berpendidikan tinggi. Salah satu faktor yang dapat mempengaruhi keputusan pihak orang tua terhadap anaknya salah satunya yang menonjol adalah faktor pendidikan keluarga.

Peran orang tua juga menentukan remaja untuk menjalani pernikahan di usia muda. menurut Al-Gifari(2002), orang tua juga memiliki peran yang besar untuk penundaan usia perkawinan anak

Orang tua juga memiliki peran yang besar untuk penundaan usia perkawinan anak Hal ini sejalan dengan penelitian yang dilakukan oleh Nurhajati, dkk ,2003) yang mengungkapkan bahwa keputusan menikah di usia muda sangat ditentukan oleh peran orang tua.

Ada juga faktor ekonomi. Oranmg tua kadang mernikahkan putrinya karena himpitan ekonomi, biar menurangi beban. Faktor ini sepertinya kurang masuk akal bahwa banyak perempuan muda yang usia 15-18 tahun sudah 3 kali kawin cerai. Setelah di telusuri ternyata karena faktor ekonomi. 
Penyebab lainnya karena ada peningkatan status sosial.pada banyak kasus ornag tua menikahkan anak perempuannya meskipun usianya masih dibawah umur kebanyakan baru lulus

smp atau Madrasah Tsanawiyah karena anak gadisnya sudah dilamar oleh anak pengusasha kaya atau anak ornag terpandang. Orang tua tidak mempersoalkan usia anaknya yang belum cukup 16 tahun yang penting baginya anaknya sudah haid karena laki-laki yang menikahinya sudah cukup dewasa bisa membimbing anaknya dalam berumah tangga.

Pernikahan memiliki peran yang sangat strategis dalam kehidupan bermasyarakat. Pernikahan merupakan gerbang awal untuk mebentuk sebuah keluarga yang merupakan unit yterkecil dari sebuah masyarakat. Keluarga yang merupakan unit terkecil dari masayarakat terdiri darei suami istri , atau suami istri dan anaknya. Tujuan pernikahan tidak terbatas hanya pada kebutuhan biologis semata. Tujuan pernikahan memiliki arti yang lebih jauh yaitu mencakup tuntutan hidup yang penuh kasih sayang sehingga manusia bisa hidup tenang dalam keluarga dan masyarakat. Untuk mencapai tujuan mulia dari perkawinan tentunya calon mempelai harus lebih matang dan dewasa jiwa raganya sebelum melangsungkan perkawinan. Kematangan ini diharapkan dapat mewujudkan tujuan perkawinan secara baik tanpa berfikir pada perceraian dan mendapatkan keturunan yang baik dan sehat. namun disisi lain, ada fenomena pernikahan di bawah unur cukup memprihatinkan dan menarik perhatian berbagai kalangan, hal tersebut terjadi karena sebenarnya fenomena pernikahan di bawah umur seperti yang kelihatan sedikitg tetapi faktanya sangat banyak terjadi di kalangan mssyarakat. Pernikahan di bawah umur ini menimbulkan banyak masalah sosial dan dilain sisi juga menimbulkan masalah hukum, Kontroversi masalah pernikahan di bawah umur memang menjadi perdebatan terutama berkenan dari batasan usia minimal bagi seoranmg anak untuk menikah.

Ada beberapa dampak dari pernikahan dini sebagai berikut :

1) Dapat Menimbulkan Depresi Berat

Tekanan yang harus dihadapi ketika berumah tangga dapat menimbulkan depresi berat pada pelaku pernikahan anak di bawah umur. Depresi yang terjadi dapat beragam. Bagi orang berkepribadian introvert, maka menyendiri, menjauh dari lingkungan, memendam sendiri masalah menjadi pilihan ketika depresi terjadi. Berbeda dengan 
orang yang cenderung ekstrovert. Mereka akan membicarakan masalah yang dihadapi dan mencoba mencari pelampiasan untuk meredakan kekesalan yang terpendam. Akibatnya, tidak hanya diri mereka yang tersakiti, tapi juga orang lain.

\section{2) Terjadi Perceraian Karena Usia Belum Matang}

Pola pikir yang belum matang dalam menyelesaikan masalah, dapat berujung pada pertengkaran berulang. Akibatnya, perceraian tidak dapat dielakkan. Hal ini membuat angka perceraian rumah tangga di Indonesia pun semakin meningkat. Bahkan, tidak jarang orang tua masih banyak ikut campur ketika anak mereka yang menikah di usia dini mengalami masalah dalam rumah tangga, yang berdampak buruk bagi kelangsungan pernikahan si anak.

3) Pendidikan Menjadi Terhambat

Ketergesaan menuruti hawa nafsu untuk memiliki pasangan halal justru bisa menjadi bumerang bagi pelaku pernikahan usia dini. Pasalnya, pendidikan mereka dapat terhambat. Masa depan mereka kehilangan cahaya. Terutama untuk laki-laki yang harus memikirkan cara untuk mencari nafkah dan menanggung anak serta istrinya. Alhasil, pendidikan pun terabaikan sebab keinginan untuk belajar sudah tidak ada lagi.

4) Terjadinya Kekerasan Dalam Rumah Tangga

Emosi yang masih labil membuat anak di bawah usia 17 tahun mudah marah dan berusaha mencari pelampiasan dengan melakukan kekerasan terhadap anak maupun istri. Tidak jarang, barang-barang di rumah habis terbanting ketika emosi tengah menguasai. Maka, bisa dikatakan pernikahan untuk anak di bawah dapat menjadi pemicu terjadinya kekerasan dalam rumah tangga. Lantaran emosi mereka belum stabil dan masih mudah goyah. Belum ada pegangan kuat yang dapat mengendalikan amarah ketika tengah menguasai.

5) Kesulitan Ekonomi Dapat Membuat Anak Terlantar

Sebagian besar alasan pernikahan anak di bawah umur dilandasi permasalahan ekonomi. Orang tua berpikir jika satu anak mereka lepas dan menjadi tanggung jawab suaminya, maka beban orang tua sedikit terangkat.

6) Kesulitan Ekonomi Dapat Membuat Anak Terlantar

Sebagian besar alasan pernikahan anak di bawah umur dilandasi permasalahan ekonomi. Orang tua berpikir jika satu anak mereka lepas dan menjadi tanggung jawab 
suaminya, maka beban orang tua sedikit terangkat. Namun, hal itu justru menjadi beban baru bagi suaminya dan kehidupan pernikahan anak mereka. Akibatnya, anak-anak menjadi terlantar dan kurang kasih sayang serta perhatian. Sebab, orang tuanya sibuk mencari nafkah demi memenuhi kebutuhan keluarga yang terus meningkat setiap harinya.

\section{7) Muncul Pekerja Di Bawah Umur}

Menanggung beban istri di usia remaja, menjadikan kaum lelaki yang menikah di bawah usia 18 tahun harus pontang-panting mencari pekerjaan yang dapat memenuhi kebutuhan keluarga. Akibatnya, semakin banyak muncul pekerja anak yang masih di bawah umur.

\section{8) Dapat Menyebabkan Penyakit HIV}

Masa pubertas yang penuh keingintahuan dan rasa penasaran menjadikan pelaku pernikahan di bawah umur tentu ingin mencoba hal-hal baru. Namun, keinginan itu tidak didasari pengetahuan dan komunikasi yang tepat. Akibatnya, dapat menimbulkan penyakit HIV yang muncul karena aktivitas seksual yang dilakukan

\section{9) Resiko Meninggal}

Selain tingginya angka KDRT, perkawinan dini berdampak pada kesehatan reproduksi anak perempuan. Anak perempuan berusia 10-14 tahun memiliki kemungkinan meninggal lima kali lebih besar, selama kehamilan atau melahirkan, dibandingkan dengan perempuan berusia 20-25 tahun. Sementara itu, anak yang menikah pada usia 15-19 tahun memiliki kemungkinan dua kali lebihbesar.

10) Meningkatnya Angka Kematian Anak

Dari penelitian juga menunjukkan jika seorang ibu di bawah umur akan cenderung melahirkan bayi yang cacat atau memiliki gangguan kesehatan. Selain itu, ibu yang melahirkan pada usia dibawah 18 tahun juga memiliki peningkatan sebesar 60\% mengenai kematian pada bayi dan bahkan memberikan pola asuh salah pada anak karena terbatasnya pengetahuan sifat keibuan dalam psikologi.

11) Perilaku Seksual Menyimpang 
Perilaku seksual menyimpang yang merupakan kesenangan berhubungan seks dengan anak di bawah umur juga bisa terjadi karena pernikahan yang dilakukan terlalu cepat. Hal ini bisa menjadi kebiasaan atas dasar pernikahan yang juga dilakukan pada usia terlalu muda sehingga mengembangkan perilaku seksual menyimpang tersebut.

\section{Dampak positif}

1) Mengurangi beban orang tua, karena dengan menikahkan anaknya maka semua kebutuhan anaknya akan di penuhi oleh suami, dan bahkan orang tua berharap beban ekonominya juga akan dibantu.

2) Mencegah kemaksiatan, seperti terjadinya perzinahan atau kumpul kebo di kalangan remaja, dengan menikah kan anaknya orang tua akan merasa tenang, karena perzinahan atau bahkan hamil diluar nikah di kalangan remaja tidak akan terjadi.

Dampak pernikahan dini baik yang dilakukan secara terpaksa atau bukan umumnya juga akan memberikan tanggapan kurang baik dari sebagian masyarakat. Meski ada dampak positif pernikahan dini sebagai solusi untuk menghindari kelakuan para remaja yang tidak diinginkan, akan tetap terlalu banyak dampak negatif yang bisa terjadi sebab pernikahan tersebut tidak didasari dengan kemampuan dan kemandirian sehingga akan lebih baik jika dipertimbangkan secara masak masak.

\section{C.SIMPULAN}

Dari uraian diatas dapat disimpulkan dari bacaan di atas bahwa faktor pendorong pernikahan dini itu ada empat poin, yaitu: Ekonomi, Orang Tua, Pendidikan, Pergaulan, dan Adat Istiadat. Adapun dampak dari pernikahan dini terdapat dua dampak, yaitu : Dampak Positif dan Dampak Negatif. Di dalam dampak positif terdapat dua poin yakni meringankan beban orang tua dan mencegah kemaksiatan. Dan yang terakhir di dalam dampak negatif terdapat tiga poin yakni dampak terhadap pasangan suami istri, dampak terhadap masing-masing keluaganya dan dampak terhadap anak-anaknya. 


\section{DAFTAR PUSTAKA}

Abdul RahmanGhozali,Fiqhmunakahat(Jakarta: Kencana,2010),h 22

Al-Gifari, A. 2002. Pernikahan Dini Dilema Generasi Ekstravaganza. Bandung : Mujahid Press.

Eka Khaparistiadan Edward dalam Naibaho, Naibaho, https://www. google. $\mathrm{com} /$ search? $\quad$ client=firefox-b-d\&q=jurnal+faktor+faktor+pernikahan+dini

Juspin, L., Ridwan T., Zulkifli A.(2009 :89-94), Studi Kasus Kebiasaan Pernikahan Usia Dini Pada Masyarakat Kecamatan Sanggalangi Kabupaten Tana Toraja. $\quad$ Makasar: Jurnal MKMI, Vol 5 No.4.

Latif Nasarudin,(2001: 22) Ilmu Perkawinan Problematika Seputar Keluarga dan Rumah Tangga, (Bandung: Pustaka Hidayah)

Nandang M., Ijun R. 2007. Faktor-faktor yang berhubungan dengan Usia Menikah Muda pada Wanita Dewasa Muda di Kelurahan Mekarsari Kota Bandung. Jurnal Kesehatan Kartika STIKES A. Yani

Nurhajati L., Wardyaningrum D., (2013). Komunikasi Keluarga Dalam Pengambilan Keputusan Perkawinan. Jakarta : Universitas Al Azhar Indonesia.

Sarwono, S. 2007. Psikologis Remaja. Jakarta : PT Rajagrafindo Persada.

Undang-undang Nomor 1 Tahun 1974 Tentang Perkawinan

WHO. (2006). Married Adolescents, No Place of Safety. Geneva: WHO Document Production Services

Wikipedia Bahasa Indonesia, ensikolopedia Bebas http//id.m.wikipedia.org,wik.pernikanan ) dioiakses 31 juli 2019

http:// hukum. unsrat.ac .id/uu/uu____74.htm) Undang-undang RI Nomor 1 Tahun 1974 Tentang Perkawinan. 